\title{
HUBUNGAN PENGETAHUAN PERAWAT DALAM KELENGKAPAN DOKUMENTASI ASUHAN KEPERAWATAN DI RUMAH SAKIT
}

\author{
Samuel Pangihutan Sitompul \\ Prodi Sarjana Ilmu Keperawatan, Fakultas Keperawatan Universitas Sumatera Utara. \\ E-mail sitompulsamuel244@gmail.com
}

\section{PENDAHULUAN}

Dokumentasi keperawatan merupakan alat yang sangat penting yang dapat digunakan sebagai indikator sebuah asuhan keperawatan di rumah sakit.

Dokumentasi keperawatan merupakan bukti pencatatan dan pelaporan yang dimiliki tenaga pekerja medis. Tanggung jawab adalah kesediaan seseorang dalam menghadapi kemungkinan paling buruk sekalipun, memberikan kompensasi dan informasi terhadap apa yang dilaksanakannya dalam malaksanakan tugas.

Dokumentasi merupakan salah satu aspek terpenting dari peran pemberi perawatan kesehatan di area pelayanan kesehatan. Dokumentasi memiliki beberapa tujuan dalam jaringan yang rumit antara pasien, fasilitas, pelayanan, pemberian perawatan, dan pembayar. Dokumentasi adalah bukti bahwa tanggung jawab hukum dan etik perawat terhadap pasien sudah dipenuhi dan bahwa pasien menerima asuhan keperawatan yang bermutu (lyer, 2008).

Asuhan keperawatan merupakan proses atau rangkaian kegiatan pada praktik keperawatan yang diberikan secara langsung kepada klien/pasien di berbagai tatanan pelayanan kesehatan. Adapun dokumentasi asuhan keperawatan adalah bukti pencatatan dan pelaporan tentang kondisi kesehatan pasien serta digunakan sebagai alat komunikasi yang akurat dan lengkap. Catatan informasi tentang keadaan pasien tersebut merupakan dokumen resmi dan bernilai hukum ( Asmadi, 2008).

Menurut Gillies (1994) persentase penerapan standar asuhan keperawatan dikatakan baik bila mencapai standar $76-100 \%$. Namun masih banyak yang tidak memenuhi standar tersebut.

Dan yang paling memungkinkan adalah faktor yang mempengaruhi kelengkapan pendokumentasian asuhan keperawatan adalah pengetahuan dan sikap. Karena semakin kuat dan luas pengetahuan setiap perawat memberi dampak yang baik 
pada pendokumentasian dirumah sakit, serta menaikan nilai baik rumah sakit serta para pekerja medis.

\section{PEMBAHASAN}

Setiap pelaksanaan dokumentasi asuhan keperawatan sangat dipengaruhi oleh perilaku perawat itu sendiri, dimana perilaku dipengaruhi oleh tiga set faktor yaitu faktor predisposing yang terwujud dalam pengetahuan, sikap, keperacayaan, keyakinan, nilai-nilai dan variabel demografi yang mempermudah atau mempredisposing terjadinya perilaku seseorang. Penelitian Nuryani (2014) menunjukan adanya hubungan antara pengetahuan dan sikap perawat terhadap sebuah dokumentasi yang terjadi dirumah sakit.

Dokumentasi keperawatan merupakan alat yang sangat penting yang dapat di gunakan sebagai indikator sebuah pelaksanaan asuhan keperawatan di rumah sakit. Dokumentasi keperawatan merupakan bukti pencatatan dan pelaporan yang dimiliki tenaga keperawatan. Pencatatan dokumentasi keperawatan itu berguna untuk kepentingan pasien, para perawat serta seluruh tim kesehatan yang bekerja memberikan pelayanan kesehatan kepada satu orang pasien itu (Prabowo, 2017). Permasalahan yang seringmuncul di Indonesia adalah masih banyaknya perawat yang tidak melakukan pendokumentasian dengan maksimal. Perawat beranggapan bahwa pelayanan ke pasien lebih penting dibandingkan dengan melakukan pendokumentasian asuhan keperawatan.

Dokumentasi asuhan keperawatan merupakan bagian dari proses asuhan keperawatan yang dilakukan secara sistematis dengan cara mencatat tahap-tahap proses perawatan yang diberikan kepada pasien. Dokumentasi asuhan keperawatan merupakan catatan penting yang dibuat oleh perawat baik dalam bentuk elektronik maupun manual berupa rangkaian kegiatan yang dikerjakan oleh perawat (Budiman, 2013)

Pada tahun 1975 Mundinger dan Jaurou dikutip Nursalam menambah adanya diagnosa pada proses keperawatan sehingga proses keperawatan mencakup 5 tahapan, yaitu (1) Pengkajian, (2) Diagnosis, (3) Perencanaaan, (4) Pelaksanaan, (5) Evaluasi.

Serta faktor-faktor Kelengkapan Dokumetasi Asuhan Keperawatan

1) Formulir Asuhan Keperawatan 2) Sumber Daya manusia 3) Standard Operasional Rumah Sakit 4) Faktor Keuntungan bagi Perawat profesional 5) Motivasi 


\section{Komponen Dokumentasi Keperawatan}

\section{1) Pengkajian}

Pengkajian adalah pemikiran dasar dari proses keperawatan yang bertujuan untuk mengumpulkan informasi atau data tentang pasien. Pengkajian dilakukan guna mengidentifikasi, mengenali masalah - masalah, kebutuhan kesehatan, dan keperawatan. Pengumpulan data pada pengkajian merupakan kegiatan dalam menghimpun informasi (data - data) dari pasien yang meliputi unsur bio psiko sosio kultural spriritual yang komprehensif.

2) Diagnosis Keperawatan

Diagnosis keperawatan adalah suatu pernyataan dari masalah pasien yang nyata maupun yang potential berdasarkan data yang telah dikumpulkan, yang pemecahannya dapat dilakukan dalam batas wewenang perawat utnuk melakukannya. Dalam merumuskan diagnosis keperawatan dapat menggunakan pendekatan

\section{3) Rencana keperawatan}

Rencana keperawatan adalah menyusun rencana tindakan keperawatan yang akan dilaksanakan perawat guna menanggulangi masalah klien sesuai dengan diagnosis keperawatan yang telah ditentukan dengan tujuan terpenuhinya kesehatan klien. Komponen rencana tindakan terdiri dari tujuan, kriteria hasil dan rencana tindakan keperawatan yang akan dilakukan ke pasien. Langkah - langkah penyusunan perencanaan keperawatan terdiri dari tujuan dan kriteria hasil. Tujuan dan kriteria hasil disusun sesuai dengan prioritas masalah klien yang akan direncanakan untuk dilakukan tindakan asuhan keperawatan. Dengan menentukan tujuan dan kriteria hasil diharapkan asuhan keperawatan yang diberikan akan memberikan keberhasilan sesuai dengan yang diharapkan klien maupun perawat. Diagnosis keperawatan ditulis kembali pada formulir rencana tindakan keperawatan dan pada kolom diagnosis disertai penulisan tanggal serta jam ditegakkannya diagnosis. Rencana tindakan keperawatan disusun sesuai prioritas masalah klien atau sesuai diagnosis keperawatan yang sudah ditentukan.

4) Pelaksanaan Tindakan Keperawatan Tindakan keperawatan adalah pelaksanaan tindakan yang telah ditentukan, dengan maksud agar kebutuhan klien terpenuhi secara optimal. Pelaksanaan tindakan keperawatan adalah implementasi perawat terhadap klien secara urut sesuai prioritas masalah klien yang sudah dibuat dalam rencana tindakan asuhan keperawatan, termasuk di dalamnya penulisan nomor urut 
dan waktu ditegakkannya suatu pelaksanaan asuhan keperawatan. Tindakan keperawatan harus berprinsip pada tindakan yang aman, sejalan dengan komponen pengobatan dan mempunyai alasan yang jelas yang bersifat realistik. Tindakan keperawatan harus memprioritaskan peningkatan status kesehatan pasien dan pasien menjadi sumber utama pemberian tindakan keperawatan.

5) Evaluasi

Evaluasi adalah proses penilaian pencapaian tujuan serta pengkajian ulang rencana keperawatan , ditulis pada tiga kolom yaitu evaluasi formatif / sumatif, rencana tindak lanjut dan tanggal teratasi. Evaluasi menilai respon pasien yang meliputi subjek, objek, pengkajian kembali (assessment) dan rencana tindakan (planning).

6) Tanda Tangan dan Nama Terang Perawat Tanda tangan dan nama terang perawat harus tertuang dalam kolom yang tersedia pada formulir asuhan keperawatan secara jelas, sebagai bukti legal dan tanggung jawab atas pelaksanaan asuhan keperawatan yang diberikan pada klien.

7) Catatan Keperawatan

Catatan keperawatan diisi secara lengkap dan jelas setiap memberikan asuhan keperawatan maupun tindakan - tindakan yang diinstruksikan oleh dokter.

8) Resume Keperawatan

Resume keperawatan diisi setelah klien dinyatakan boleh pulang atau meninggal dunia maupun pada klien yang pulang atas permintaaan sendiri, yang berisi rangkaian secara singkat dan jelas atas asuhan keperawatan yang telah diberikan.

9) Catatan Pasien Pulang atau Meninggal Dunia. Formulir tersebut diisi sesuai keadaan klien saat itu. Jika klien diijinkan pulang untuk obat jalan, maka harus diisi secara rinci yang meliputi : keadaan klien pada saat akan pulang termasuk masalah perawatannya, jika ada luka bagaimana perawatan lukanya, diet yang dianjurkan, aktivitas, waktu kontrol, pengobatan dan dosisnya, serta pesan - pesan lain yang diperlukan untuk klien

Tujuan dokumentasi keperawatan pendokumentasian keperawatan, antara lain sebagai berikut:

- Sebagai media untuk mendefinisikan fokus keperawatan bagi klien dan kelompok.

- Untuk membedakan tanggung gugat perawat dengan anggota tim kesehatan lainnya. 
- Sebagai sarana untuk melakukan evaluasi terhadap tindakan yang telah diberikan kepada klien.

- Sebagai data yang dibutuhkan secara administratif dan legal formal.

- Memenuhi persyaratan hukum, akreditasi dan professional.

- Untuk memberikan data yang berguna dalam bidang pendidikan dan penelitian.

\section{Manfaat Dokumentasi Keperawatan}

asuhan keperawatan menurut Nursalam (2008), dokumentasi asuhan keperawatan menurut beberapa aspek berikut :

1. Aspek hukum : Dokumentasi keperawatan yang dibuat merupakan aspek legal didepan hukum. Dokumentasi merupakan bukti catatan dari tindakan yang diberikan dan sebagai dasar untuk melindungi pasien, perawat dan institusi.

2. Kualitas pelayanan, komunikasi: Melalui audit keperawatan dokumentasi keperawatan dijadikan alat untuk mengukur dalam membandingkan antara tindakan yang diberikan dengan standar yang dijadikan rujukan. Dengan demikian dapat diketahui apakah dalam bekerja telah sesuai dengan standar yang ditetapkan.

3. Keuangan: Dokumentasi yang baik dan teliti akan menjadi bukti bahwa tindakah telah dilakukan oleh perawat. Dan dengan dokumentasi ini maka besarnya jasa yang diberikan akan diberikan sesuai dengan aturan yang ditetapkan ditempat masingmasing.

4. Pendidikan: Dokumentasi keperawatan dapat dijadikan sebagai rujukan bagi siswa-siswa perawat.

5. Penelitian keperawatan dengan menggunkan data-data sekunder akan sangat bergantung dengan kualitas dari dokumentasi keperawatan yang dibuat. Kesalahan dalam membuat atau pengisian dokumentasi yang tidak lengkap akan membuat informasi tentang riwayat pasien menjadi kabur.

Hendaknya memperhatikan hal di bawah ini:

1. Harus menggunakan standar terminologi yang terdiri dari pengkajian, diagnosis, perencanaan, pelaksanaan/implementasi dan terakhir evaluasi dari proses perawatan yang diberikan. 
2. Mengumpulan serta mendokumentasikan data yang diperoleh sesuai dengan keadaan yang terjadi pada pasien ke dalam catatan yang permanen.

3. Menegakkan diagnosa keperawatan berdasarkan data yang telah dianalisis dengan cermat dan akurat. Mendokumentasikan hasil observasi secara akurat, lengkap sesuai dengan urutan waktu kejadiannya.Merevisi rencana asuhan keperawatan berdasarkan hasil yang diharapkan dan yang ditemukan terhadap pasien

4. Demikian juga dengan pengembangan dokumentasi asuhan keperawatan, yang telah diuji coba dan dikembangkan, dari evaluasi yang telah dilakukan terhadap pengguna didapatkan respon yang baik, perawat menjadi terbiasa dan merasa lebih nyaman bekerja dengan menggunakan komputer (Ammenwerth et al., 2003).

\section{PENUTUP}

Kesimpulan dan Saran

Kelengkapan pendokumentasian asuhan keperawatan di Rumah Sakit Umum secara bermakna dipengaruhi oleh tingkat pengetahuan dan sikap perawat

Dan sebaiknya memberikan pendidikan, pelatihan dan seminar yang berkaitan dengan rekam medis dan catatan dokumentasi keperawatan serta mencari kelengkapan factor-faktor yang berpengaruh terhadap kelengkapan dokumentasi keperawatan.

\section{REFERENSI}

Asmadi. (2008).Konsep dasar Keperawatan, Jakarta. EGC.

Agung, P. 2009. Analisis pengaruh faktor pengetahuan, motivasi dan persepsi perawat tentang supervisi kepala ruangan terhadap pelaksanaan dokumentasi asuhan keperawatan di Ruang Rawat InapRSUD Kelet. Jepara.https://core.ac.uk/download/pdf/11716145.pdf. Diunduh 18/01/19.

Prabowo, T. 2017. Dokumentasi keperawatan. Pustaka baru press: Yogyakarta Aini, N. (2018). Model Keperawatan beserta aplikasinya dalam keperawatan. Malang: Universitas Muhammadiyah Malang

Haryanto.(2007). Konsep dasar keperawatan dan pemetaan konsep.Jakarta: Selemba Medika 
Huriah, T.(2018). Metode studentcenter learning aplikasi pada pendidikan keperawatan .Jakarta: Prenademia Group

Komarudin.(2018).Pendidikan keperawatan berkelanjutan dalam pencapaian suitability profesionalisme keperawatan. 3(2).139-151

Mangole, E. J., S. Rompas dan A. Y. Ismanto. 2015. Hubungan perilaku perawat dengan pendokumentasian asuhan keperawatan di cardiovascular and brain center RSUP prof. R.D. Kandou, (online), E-Journal Kperawatan (e-KP) Volume 3, No. 2, Otober 2015, https://media. neliti.com /media/ publications/109372-IDhubungan-perilakuperawatdengan-pendoku.pdf. Diunduh tanggal 04/05/2018.

Martini, 2007. Hubungan karakteristik perawat, sikap, beban kerja, ketersediaan fasilitas dengan pendokumentasian asuhan keperawatan di Rawat inap BRSUD Kota Salatiga. (online). http://eprints.undip.ac.id/18127/1/ MARTINI.pdf. Diunduh tanggal 26/04/2018.

Supartini, Y. (2004). Konsep dasar keperawatan anak. Jakarta: EGC

Simamora, R. (2009). Dokumentasi Proses Keperawatan.

Simamora, R. H., Purba, J. M., Bukit, E. K., \& Nurbaiti, N. (2019). Penguatan Peran Perawat Dalam Pelaksanaan Asuhan Keperawatan Melalui Pelatihan Layanan Prima. JPPM (Jurnal Pengabdian Dan Pemberdayaan Masyarakat), 3(1), 25-3 